\title{
Assessing the Impact of Technology Learning and Assessment Method on Academic Performance: Review Paper
}

\author{
Ragad M. Tawafak ${ }^{1,2^{*}}$, Awanis BT Romli ${ }^{1}$, Ruzaini bin Abdullah Arshah ${ }^{1}$, Rana A. Saeed Almaroof ${ }^{3}$ \\ ${ }^{1}$ Faculty of Computer Systems and Software Engineering, University Malaysia Pahang, 26300 Kuantan, Pahang, MALAYSIA \\ ${ }^{2}$ Faculty of Information Technology Department, AlBuraimi University College, Buraimi, OMAN \\ ${ }^{3}$ Faculty of English Language \& Linguistics, AlBuraimi University College, Buraimi, OMAN
}

Received 9 November 2017 • Revised 26 February 2018 • Accepted 6 March 2018

\begin{abstract}
Technology enhancement learning is a process that leads to deep point of learning and adds knowledge of technologies. Various studies shed light on technology development and its effect in educational sector. The aim of this integrative review is to examine the current evidence of the impact of technology learning on student learning and academic performance in courses requiring collaborative or activities. The authors searched electronic databases for relevant articles, with different learning techniques. 24 articles met the requirement of paper, it's collected from (2011-2017). Three themes of techniques used for student learning outcomes, includes technology enhanced learning, assessment method and faculty experience on academic performance in universities with technology use. The final results of this paper show the relationship between what has been done and the factors used by the authors. Also the future work needs more use of technologies in different phases of learning process.
\end{abstract}

Keywords: Student Learning Outcome (SLO), Technology Enhancement Learning (TEL), Academic Performance (AP), Faculty Experience (FE)

\section{INTRODUCTION}

An early look at historical development of educational institutions through different phases shows that these changes are closely linked to differences in each phase. Start with simple training in classical education to virtual education in that the educational system should reflect the educational needs of technology learning. Technology enhancement learning (TEL) applications are a new important area for study in high educational institutions. They are growing in popularity as a practice nowadays type of e-learning means to mediate, support active learning and authentic collaboration among students by web based technologies. They make a new mix between teachers and learners in responsibilities of learn and use technologies. This method will give flexibility to learner, use and read more with confidence of learning ways to be assessed by faculties (Benson, 2011; Wang \& Hannafin, 2005). The learner knows the process phases include the mechanism of analysis, develop and evaluate. It divided to topic analysis, material used to develop, way of evaluating the outcomes, the techniques of delivering for assessment (Grover, Miller, Swearingen, \& Wood, 2014). There are many types of applications used in technology learning. These applications may include, for example, video based programs, Wiki, and Google forms internet which are types of the Web 2.0 technology. These applications allow learners to interact with each other within a virtual learning environment rather than passively listen to an instructor. In addition collaborate in groups of Web page accessed via the internet, offering a space for users to add text, pictures, videos, online communications and links to other Web pages.

The technology triggers the learners to work in an unlimited time, peer assistance, teacher guidance, and team work students that trigger student learning and assessment as a learning outcome. These data tell the faculty and administrators what their students learn and achieve. This virtual connection improves student confidence and develops their knowledge skill and technology experience in a way to increase collaboration and results. TEL has

(C) 2018 by the authors; licensee Modestum Ltd., UK. This article is an open access article distributed under the terms and conditions of the Creative Commons Attribution License (http://creativecommons.org/licenses/by/4.0/). $\nabla$ raghad@buc.edu.om (*Correspondence) $\boldsymbol{\nabla}$ awanis@ump.edu.om $\boldsymbol{\nabla}$ ruzaini@ump.edu.my 


\section{Contribution of this paper to the literature}

- The effectiveness of technology enhanced learning on technology learning and the assessment method to improve the academic performance.

- This study discover the effect of teaching experience and technology learning development to be translated into positive student learning outcomes.

- The technology integrated tools emphasis on student interest in order to develop their academic performance.

increased the speed of transferring knowledge, also the method of transferring from faculty to students. The method is about learning and teaching thinking and methodologies within the context of outcome-based education in the learning environment.

The influence of technology on student learning can be viewed from clarifies how students learn, inquire, and reflect upon past experiences to build, refine and develop new knowledge of teaching and learning practices. In the early systems, students used traditional textbooks and normal exams to submit their performance and knowledge. Now a day, the students use different strategies employed by teachers and students in development of learning process. Using these applications (wiki or e-learning) tools is like an online conversation that gives opportunity to students to learn from other studies. The students can connect by internet with open discussion and with common groups under high experience of faculty's supervision, to create different discussion areas and develop different techniques with interest of use to improve their knowledge and scores with share perceptions on topics (Salajan \& Mount, 2012).

Additionally, by the incorporation of technology, TEL might also be better able to meet the needs of the current generation of students and improve their activities, support and ability to learn while being surrounded by computers in their daily life (Lancaster, Wong, \& Roberts, 2012).

In this step of assessment, the research focus on some important factors include first the student learning outcomes by e-learning to show the real outputs of universities, second the faculty qualification and experience of staff teaching faculties, third the assessment method used in TEL to prove the development. Essential learning outcomes mean condition of comprehension, expertises, thoughts, and occurrences of students in the followings aspects: civic commitment, thinker capability, communication and interpersonal relatives that need a lot of courses (Kleebbua \& Siriparp, 2016). The new technology learning is need for providing training courses to academic staff members at the universities in order to utilize eLearning in their courses, especially how to deal security and different learning material (Aldiab, Chowdhury, Kootsookos, \& Alam, 2017). The use of TEL help to be better in research way for faculty and in self-assessment used to evaluate FE, students performance level, and course material evaluation by using these technological tools. These requirements need to be well observed and respected within academic regulations.

\section{RESEARCH GOALS AND DESIGN}

The main objective of this study focus on there is a need to investigate whether TEL impacts on the SLO, assessment method, teaching and learning experience. This impact can measure through student academic performance that mean level of SLO and the way of assessment method used in education in a positive way in comparison to traditional learning. Also measure the faculty experience with TEL usage in development of teaching method impact on whole academic performance.

The secondary objectives were identified to achieve the main objective:

- To perform a literature review this will assist in identifying what TEL entails to improve academic performance

- To review current empirical research on the topic.

- To summarize conclusions based on the empirical results.

The students' experience in TEL environments varied according to the different educational levels of courses they took and services offered in their universities. In general, they used an "online learning management system (Moodle)", use of collaborative writing platforms (e.g. Google Docs), and used mobile devices (laptops) (Barak \& Levenberg, 2016).

\section{REVIEW METHODS INSTRUCTIONS}

This fragment includes an importance on teaching, experience, and assessment with TEL. The focus here, as a result, is on the organization and institutional systems for supervision the excellence of student knowledge by TEL, 
Table 1. Database of searched articles

\begin{tabular}{lcccc}
\hline Database & TEL & SLO & TE & TOTAL \\
\hline IEEE & 3323 & 1139 & 2454 & 6916 \\
\hline Science Direct & 51208 & 39958 & 49192 & 140358 \\
\hline Scopus & 732 & 2401 & 4315 & 7448 \\
\hline
\end{tabular}

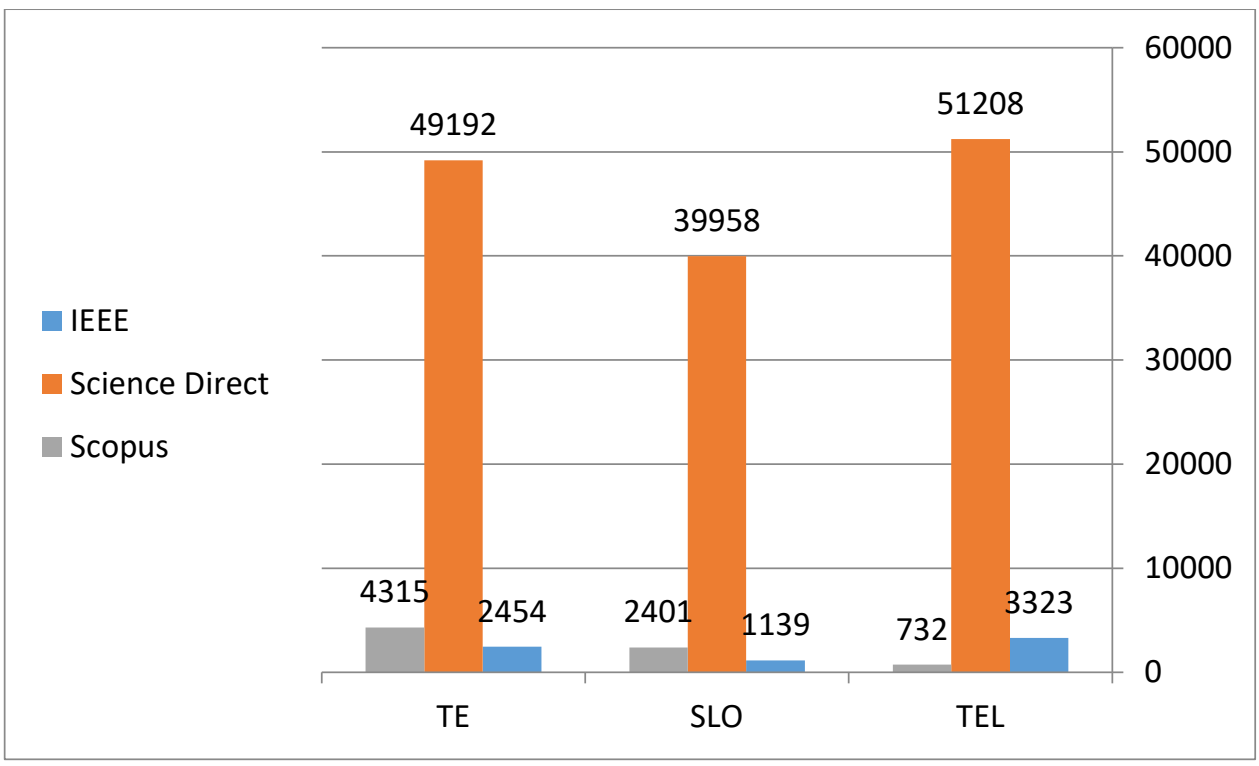

Figure 1. The three databases for research articles results with main factors

and not on the specific programs themselves. These points include Student Learning Outcomes, Teaching Experience, and Technology Enhanced Learning, which fundamentally considered all criteria points as one complete set for accreditation process standard with academic issue.

Lin, Chen, and Liu (2017) indicated that the terms academic performance, learning outcome, or learning achievement expressed the same meaning of students' academic learning outcome. Learning outcome is an indicator to measure learners learning effect and support evaluation of teaching quality. SLO would be affected by assessment method, curriculum design, and teaching experience characteristics.

This paper focus on three major parts in search area and selected articles retrieved from database related to SSCI, and Scopus like downloaded of IEEE (6916), Science direct (140,358), Scopus (7448) with special keywords related to : teacher experience (TE), TEL, and SLO. The results of these key words give a lot of papers as shown in Table 1 that based on the recent reviewing studies through 2011-2017 with different title majors. The major criteria for selecting these three factors based on standards of academic performance for accreditation process. There are many restricted papers removed because of dissertation, duplications in search, review papers, advertisement of university teaching method, teaching catalogs, university regulations and management issues, and papers based on techniques samples more than student performance. At the end the researchers selected only 24 papers as a sample to give an overview about the target of the three major factors.

The table above shows that science direct database has enormous number of articles that are related to the research object in Figure 1. It gives the percentage of the highest present comes with more focus on the TEL, so this research gives chance to include the assessment method technology to work in parallel with the needed technology to enhance the development of the academic performance which is part of the learning process.

\section{LITERATURE REVIEW}

The literature review of this paper sheds light on an integrative review of the literature to identify which standards, that can reflect best practice, are currently in use that focuses on different technologies. The total number of these papers is 24 which related to TEL techniques, with their effect on student learning outcomes, and faculty experience. The different technologies and applications used currently in the universities could directly or indirectly interfere with the graduation outcome and student achievements. 
Table 2. Categories of moderator variables

\begin{tabular}{|c|c|}
\hline Moderator variables & Categories in analyzed papers \\
\hline Allocation & $\begin{array}{l}\text { - Pre-studies select different topics on students prefer, or college select neither groups of interest } \\
\text { students with TEL }\end{array}$ \\
\hline Educational levels & $\begin{array}{l}\text { - Different studies in Secondary schools } \\
\text { - Undergraduates (diploma, high- diploma, bachelor) }\end{array}$ \\
\hline Subject matter & $\begin{array}{ll}- & \text { Information technology } \\
\text { - } & \text { Business and Accounting } \\
\end{array}$ \\
\hline Duration & $\begin{array}{l}\text { - Short courses in summer within 6-7 weeks } \\
\text { - } \quad \text { Long courses in semester within } 17 \text { weeks }\end{array}$ \\
\hline Communication & $\begin{array}{ll}\text { - } & \text { Face to face conversation } \\
\text { - } & \text { Online chat /Email message connection } \\
\end{array}$ \\
\hline Quizzes & $\begin{array}{ll} & \text { Traditional theoretical quizzes } \\
\text { - } & \text { Online exams/ electronic assessment } \\
\end{array}$ \\
\hline
\end{tabular}

Table 3. Categories of mediator variables

\begin{tabular}{cl}
\hline Type & Description \\
\hline$T$ & $\begin{array}{l}\text { Used full tool programs (technology impact) using portal system in on-line course instead of traditional face to face } \\
\text { learning. Used with far away distance in e-learning }\end{array}$ \\
\hline TG & $\begin{array}{l}\text { Use of tools with teacher guidance. It mixes between traditional teaching and e-learning on some programs to improve } \\
\text { SLO and AMT though activates teamwork assignment assessment and increased student confidence of applied } \\
\text { technology with course study. }\end{array}$ \\
\hline ThW & $\begin{array}{l}\text { Traditional work that only use class work and submitting hard copy exams and evaluations without use of new } \\
\text { technology to enhance student skills. }\end{array}$ \\
\hline
\end{tabular}

\section{Three Key Challenges for Technology Enhancement Learning}

This part presents the types of challenges that may face TEL in relation to three factors which affect the process of gaining AP and university accreditation. These challenges include the three elements of this study which are the development of student learning outcomes through assessment method, faculty experience, and faculty familiarity with technology which is based on enhanced learning tools. The TEL tools have to pass through four applicationusages which are the Wiki chat- online conversation, Video programs, Audio-photo programs, and Google forms drive-applications. These are used for online evaluation to assist university outcomes.

The researchers of these studies state that the basic elements are related to one of the three options ( $\mathrm{T}$ : used tool only, TG: used tool with teacher guidance, and ThW: used theoretical work only). Most of analyzed papers show the work moved toward theoretical work in assessment method more than toward of using tool in evaluation element. This result supports the aims that are suggested by the researcher of electronic support the major three key elements. These analyzed articles give identification to specific technology but still they do not show how it reflects positively on more than collaborative work between faculties, and how to develop student's skill to improve the comprehension level and interest in learning.

\section{The Moderator and Mediator Variables}

The moderator variables used in this study are given in Table 2. The table explains all the six variables of allocation, educational level, subject matter, duration, communication, and quizzes used in pre-analyzed studies where they measure student's academic performance at the end of this review paper. The analyzed papers show two different types of quizzes are used following the traditional way of assessment and online exams. Also the traditional face to face classroom conversation and the online communication between faculty and students, and student peer student are also considered as a means of communication. In Table 3, it gives clarification on three techniques of teaching process are use.

From the two Tables 2 and 3, it shows the previous studies consideration points and their major focus about type of services applied between two sides of the learners, teachers and the other side the location and level of elearning used. But still a lot of studies did not give explanation and real achieved points on the assessment of learning used by teachers and how with TEL could produce high level of evaluation and moderation of all scores that affect in positive and beneficial results on student academic performance. From this gap the researchers of this paper comes to identify all types of services given and explain include factors, methodologies, and findings from 24 selected papers published in (2011-2017). Additional work it gives conclusions and suggestions to next type of TEL techniques used by faculties in assessment method that could help to increase the impact of academic performance. 


\section{Technology Enhancement Difficulties}

There are many restrictions that make it difficult to use the efficiency of technology tools or BL techniques in institutions and universities of HEI. It identifies the strength and weakness of giving market offer because they focused on service delivery more than outcomes. These types of application technologies are mostly used for business production to firstly increase the company income values, and secondly to improve the productivity of electronic use rather than relying on technology in developing knowledge skills of university performance (UP). In addition, develop the understanding of application tools, and experience with new generation of technologies. The updated technologies and applications are used currently in the universities, this usage may affect directly or indirectly the UP.

Another type of difficulty focuses on the time consumed in collecting evidence and in analyzing the data which could reflect the performance of manage in slow off the accreditation process (Pinedo, Chiyón, \& Pérez, 2012). The educational levels and skills of students and administrator can be enhanced by using the supported the learning process (Graffigna, 2015). Also still the educator-student learning experience can't be replaced by technology due to human and social elements which technology lacks (Joseph, 2012). The experience of the expert faculties and administrative has a crucial role in improving UP and TEL. The answer to this difficulty is dealt with through the implementation of the experiential analysis within the application method in the higher education sector.

\section{RESULTS AND DISCUSSION}

\section{The Quality of Student Achievement as Student Learning Outcomes using TEL}

At this point of the study, the main focus is on SLO and student exams achievements. The educational courses answer the questions that are related to: a) How the students' shooting process have been carried out based on the uniqueness's standard and on the fundamental learning outcomes?, b) How the learners can accomplish the necessary learning outcomes by applying technology learning (Hashim \& Majid, 2015). The student is the main part of the whole educational process and that there are many technologies involved such as an email; online videos, wiki chats, Google forms which can be viewed from different browsers and from different operating systems (Aldiab et al, 2017). When student used these technologies, his or her learning outcomes could be developed more. There are many studies concerned with student's achievements and many of them give good ideas and impression about how to improve the comprehension skills and attitudes, SLO and achievements. Most of these outcomes are evaluated through a computational model based on Web-based survey research as an important technique for behavioral research of some populations.

The implementation of well accomplishment with high quality in BL courses and study plan programs needs both planning and steps design. The mediums of learning identified are computer-based; video conferencing; satellite, webcast and CD-ROM. The education technology involves many learning types different from online communication, wiki chat, and different Google services (Joseph, 2012).

In online courses with most active application techniques allowed, or aid used technology course material, Students can access the open access courses; by using their email and passwords; submit their homework and projects through this system. Additionally, they are allowed to choose how they will access the necessary learning materials, and select the suitable group to join the sharing material (Yigit, Koyun, Yuksel, \& Cankaya, 2014). Owning in TEL, the students have their opportunity to learn more and get benefits of education and be more confidence, more inspire to connect with others without need to face to face meeting and fixed time and schedule to learn.

The right implementation ensures the value of the learning outcomes assist the students' transition to fresh approaches in the field of training and learning. Sharing outcomes and education skilled from the newly transitioned blended program can suggest dating the future philosophy innovations and investigating (Posey \& Pintz, 2016). The use of TEL helps to improve the SLO. They include reference to both self-assessment that is used to evaluate both faculty teaching method and students' performance, and course material evaluation based technological tools. These requirements need to be well observed and respected within the academic regulations.

In a study presented by Liu (2016), the researcher tries to use video BLOG to make an optimization for SLO in universities. He tries to make an investigation by using video class in face to face interaction that could enhance the university student learning performance and improve outcome. The method depends on emerging Web 2.0 application technology in supporting the process of teaching and SLO (De Wever, Hämäläinen, Voet, \& Gielen, 2015). He employed an assessment technique to get the evidence for the actual student performance outcomes. This paper raises two questions which are as follows. The first question is that if the students can acquire the needed speaking skills using video blogging more effectively than who cannot make use of this advantage. The second question is that if they found this way more interesting in their communication with native speakers more than 
their counterpart. The sample is experimented by self-selected or judgment. This result indicates that the use of video blog helps in improving students' learning outcomes.

Strang (2013), on the other hand, proposes a new idea which is concerned with asking instructors to form a kind of collaborative study group. The study helps in decreasing the gap between student low achievement and highquality requirements. It's built on four significant predictors which are student's achievement, pedagogy, accumulated grade achieved and student gender. All these factors used in an arithmetic formula are applied by few faculties as integrated of knowledge concepts with the program. He used TEL to evaluate the efforts of faculty teaching could be approved through standardized exams during e-learning and enhanced learning through course runtime. The advantages of using new and updated computer technologies increase the SLO and AP, and allow students to more self-control of own their knowledge and type of learning to achieve learning goals (Laurillard, 2008). The generalized use of (TEL) could improve the online evaluation with high degree of satisfaction towards their grades and knowledge skills, especially when they are free to work any time without being limited in time.

In conclusion, the researchers in the tackled papers suggest strategies to develop a common framework for technology enhanced learning that is related to improve the knowledge skills required by the students, and academic performance. This in turn can help in facilitating the use updated technology to improve the whole learning process. The suggestion here is to get TEL advantages, and student can use their access authority to login and upload their assignments, quizzes, reports within duration time, without need to print hardcopy and fix real time to meet the faculty and discuss the document. In addition, students' course performance can be evaluated; students and the teachers can meet online and realize interactive learning activities. The point of using technology system is to increase the whole achievements of SLO that matching with accreditation to develop quality assurance strategies. The revision helps in keeping the balance factor and using the updated technology.

\section{The Effect of TEL with University Outcomes and Teaching Experience \& Quality}

Performance studies at the university level are highly dependent on the ways of how people build a sense of the rules, implement the balance sheet in their own organization and deal with policy contexts to get accreditation. The manager is also responsible for ensuring the University has a sufficient infrastructure to maintain productive and high quality delivery of both courses and programs (Aldiab et al., 2017). In education technology can enhance teaching and learning method if the center of attention is on education objectives and technology can be used as a possible technique. Many presented paper gave an understanding of expression education technology and how it affects on teaching and learning by highlighting its strengths and the challenges which slow down meaningful education experience for both teacher and learner (Joseph, 2012).

Naidu and Derani, (2016). This paper intends to compare between public and private universities to investigate their quality standards. The essential topic is related to students' satisfactions. The sample included the undergraduate students associated with tertiary education. The paper proposed that student requires the best of both quality and education. By using survey evaluation (SERVQUAL) universal method tool generate the results. The main focus is on the use of different technologies and applications in the current universities. This usage may affect directly or indirectly the university performance, targets of graduation outcomes and student achievements.

The education technology can lead to active learners who master their learning content and increases learner modes of critical thought ensuring students' growth at their own level, use most techniques of multimedia applications, video application, have greater collaboration skills and research skills (Joseph, 2012). In the main courses such as programming and analysis or hardware-based courses are taught face-to-face and the other courses are taught online. This type of teaching could improve the quality by highlights level of student satisfaction. Malik and Coldwell-Neilson (2016). They used an ADRI model in developing teaching method instead of traditional way of education. They came out with improving in students experience and develop in their achievements.

The investigation includes data that are related to programs and practices which are later linked with major and resultant education (Bourke, Ryan, \& Lloyd, 2016). There is a multiplicity of innovative performances that have been developed to connect students. It is composed of "team-based learning, project-based learning, and community-based learning" (Michelson, Tong, \& Reeves, May 2015). The TEL works just as well as traditional teacher learning, help in develop student confidence and skills

A newly proposed study by (Posey \& Pintz, 2016) this can be implementing by new technology (T3) of teaching, transforming, and technology project. This blended method is used to develop the teaching goals, to identify the course challenges, and to increase the critical thinking and active learning. The main method is based on four components which are 1) the quality ratings solved by peer reviewing, 2) quality matters which are done by both preprogram and post program of digital literacy skills, 3) assessment of student satisfaction and 4) the interview with teachers to get feedback in the proposed format. The results revealed that the two suggested ways of teaching which are face to face interaction and the blended format are working in high interest result for improving quality. 
Chmiel, Shaha, and Schneider (2017) improved a comprehensive evaluation framework for all actors. The study mostly focuses on students, teachers and institutional aspects of BL in higher educational institutions. The method is divided into three stages. The first stage is the Establishment of standards \& concept of evaluation. The second stage has to do TEL with the tools of student, faculty, and administrator. The third stage is the implementation of the program on going evaluation. The finding shows that university policy tends to accept new method of teaching based on online classes and technology experience for both teachers, administrators.

The final suggestion of all previous studies is that all authors try to develop techniques that assist the educational functions including students, administrators, faculties, managers, directors depending on the portal system as a facilitator and specific technique tools (Apandi \& Arshah, 2015). The researchers find that there is a gap as far as students' needs and faculty's needs. There are still uncovered points that are related to evaluation or assessment of student's results and mark distribution. Some of them, however, are explained in an effective manner. For individual work, or as team work evaluation. It is based on the use of hybrid technology in teaching which makes a comparison between traditional method of faculty teaching and the use of available e-learning library systems. The suggested techniques to develop the university outcomes could be checked by training of special experienced faculty staff can improve university accuracy. Therefore, it becomes HEI responsibility to make this requirement clearly available to prospective students.

\section{The Effect of TEL with Assessment Method to Improve SLO}

The assessment method used in universities based on the traditional way of marking assignments of learners without clarify the rule of mark distribution. Also some studies give mark distribution and their relation with course objectives in traditional formal way. Less number of studies converts the TEL tools to be used in assessment method and show full teacher work on portal systems ( $\mathrm{Lin} \& \mathrm{Wu}, 2016)$. One of the new article that is proposed by Wilby, Zolezzi, Rachid, and El-Kadi (2017) reviews a published and online literature showing how to develop a full assessment framework to do the same. The main method starts from appointing a coordinator of assessment by the dean. The appointment is carried out by a committee which consists of faculty, students and administrative. The committee will review papers and extract more key points to approve the accreditation strategy. Then data will be categorized into different majors depending on the review points. This categorization has different types of evaluation mechanisms. First, they work on curriculum development. Second, the gaps are identified within the program learning outcomes and summative assessments. Finally, the selected courses should support teachers in developing and improve the examinations and assignments. After the implementation the previously stated phases, it has been found out that the there is a need to include mission / vision, standards and the satisfaction of the students, faculty, and other stakeholders.

In the case of worldwide programs, the access standards are clarified by the distant student source.

As such, HEIs may need undergraduates to achieve higher standards. The analyzed papers, that handle AMT, still suffer from creating the right connection between teacher assessment and student assessment. This is due to the fact that there are no clear rules of single or group work of assessment. The objectives of the proposed work is to find the most appropriate technology work that can enhanced learning and to link them with other factors to develop the whole points as one set. These results may help in facilitating the university accreditation approval results. 
Table 4. The analyzed papers based on factors affect related to TEL

\begin{tabular}{|c|c|c|}
\hline Author & $\begin{array}{l}\text { Experiment } \\
\text { Studies }\end{array}$ & Moderator Variables \\
\hline $\begin{array}{l}\text { Bell } \& \text { Youngs. (2011) Substance } \\
\text { and show: Understanding } \\
\text { responses to teacher education } \\
\text { programme accreditation } \\
\text { processes }\end{array}$ & $\begin{array}{l}\text { Research use } \\
(\mathrm{k} 9-\mathrm{k} 12) \text { high } \\
\text { school to be } \\
\text { tested of } \\
\text { program }\end{array}$ & $\begin{array}{l}\text { Influence of teacher assessment and way of } \\
\text { teaching used, Implementation to be } \\
\text { familiar with understand program, use } \\
\text { interview to accreditation policy, Data } \\
\text { collection \& technology needs Classify } \\
\text { factors (gender, teaching course, Role) by } \\
\text { NCATE moved outcomes standards with HE } \\
\text { required to social, professional in } \\
\text { Connecticut, teacher evaluation, generate } \\
\text { new dataset. }\end{array}$ \\
\hline $\begin{array}{l}\text { O'Bannon \& Britt. (2011) } \\
\text { Creating/developing/using a wiki } \\
\text { study guide: Effects on student } \\
\text { achievement }\end{array}$ & $\begin{array}{l}\text { High school } \\
M=3.42 \\
S D=0.569\end{array}$ & $\begin{array}{l}\text { The study exam the effectiveness of use wik } \\
\text { on teachers, the increase of knowledge, wiki } \\
\text { frequency and communication habits. } \\
\text { Experiment the effective, Wiki characteristic } \\
\text { are unique, celebrative, simple, open } \\
\text { editing, frequency of use include reader, } \\
\text { writer, editor roles; and communication with } \\
\text { increase teacher knowledge of Web 2.0, } \\
\text { communication of wiki. }\end{array}$ \\
\hline
\end{tabular}

\section{Method and Results}

In method construction, the accreditation process has two steps, the teacher education and NCATE standards. The program certified about $40 \%$ per year new teachers while institution includes many parts (program size, financial part, institute size). The participant 89\% (17of 19 members) like dean, senior faculty, new faculty joins the interview with varied questions. They agree with conceptual framework was with varied questions. They agree with conceptual framework was
positive with programmes and clear on collective values. The faculty creates new assessment way for accreditation requirement plus use of current assignments. Each institute has evidence of substantive and symbolic changes. This needs (rethinking, relearning, revision). The framework use project based learning to put student in situation to solve real problems. Participant teachers (113), students (103) and (n) information, $5 \% 0$ need in secondary school, $13 \%$ for special needs. $77 \%$ female, $23 \%$ male in age of $23-24$ out of normal population of 275 . The procedure divided to group read, group use wiki videos, group used learn to know, then group to use project wiki. Two type of test pretest scenario, ( $t=29.186), p<0.001$ and posttest definition ( $\mathrm{t}=17.810)$. Finding are Wiki can increase student knowledge but still less in posting or modifying, then using email is more, and in class conversation its most benefits to student skills. Finding used t-test as numerical score to measure the exam by faculty electronic evaluation (Eval). The method use predetermine score that student should pass otherwise he have to remedial in freshman year.

1106 student

33 teacher, 97 Match specific student learning records with

Beleche, Fairris, \& Marks, (2012) section specific course evaluation through fixed

Do course evaluations truly reflect student learning? Evidence from an objectively graded post-test

measured used course and use individual students learning

for M (4.34- by high-stakes post-test to central of SLO, 4.65) and SD through online exams and technology of (0.66- 0.95) assessment.
Abdullah, et al, (2012) Development of a Quality Assurance Plan in Line with UKM's Status as a Self-accreditation Institution and Research University

Un-weights

values
Undergraduate core processes for self- accreditation and Research project, academic program, services, \& technology support to Improve quality by teaching, learning, \& evaluating process in UKM. Many students can repeat it till pass to move for next academic year. Eval, results shows $62 \%$ pass, $58 \%$ female, average of GPA $=3.42$. The empirical method use special equation to evaluate student performance, t-test give $0.00,0.018$ for lecture and posttest. Many factors and characteristics used with course learning, and subsequence of grade improvement with different $\mathrm{M}$ and SD and correlation coefficient. Robust positive, statistically significant, association of SLO \& evaluate.

The paper develop QA plan for academic program accreditation. It ensures the integration between education and research service to accreditation process. The audit identifies the procedure to check (vision, mission, curriculum development, assessment, etc.) this approved through determine create policies, documented processes, evaluation results, and continuous improvement. The self-accreditation

Joseph, J. (2012)

The barriers of using education technology for optimizing the educational experience of learners

Undergraduate
Un-weights
values

Technology used teamwork with traditional teaching (teacher-student technology experience to improve their skills and knowledge) it impacted positively on the experience of the learner. status needs improving quality, teaching, and learning.

Quantitative study on the nature of technology based learning and how this practice contributes to teaching and learning. Finding shows that educators can't replace learning by TEL only. $80 \%$ shows good results, while $20 \%$ indicate It's not the best tool. While other studies give good use if used in educational technology experience. Total results $45 \%$ who used technology in problem solving. $42 \%$ used for experiments, $17 \%$ develop demonstrator, $13 \%$ for design product. Outcomes positive attitude by teacher and learner.

Technology creates personal learning, development, assessment, digital content, $\mathrm{BL}$, online courses, tools and devises. Three major challenges facing the nation's

Schwartzbeck, \& Wolf (2012) The Digital Learning Imperative: How Technology and Teaching Meet Today's Education Challenges

Undergraduate education system access to good teaching $(\mathrm{N}=100) \quad$ tight budgets, and boosting student achievement. This report outlines how digital learning can connect middle and high school students with better teaching and learning experiences.

How institutions working to increase

Graham, et al,(2013)

A framework for institutional adoption and implementation blended learning in higher student capacities to succeed in BL, online in three terms of Awareness, adoption, education $\begin{array}{ll}\text { Un-weights } & \text { growth of BL. University policy to accept } \\ \text { results } & \text { new method of teaching by online classe }\end{array}$ and technology experience for both teachers, administrator. In three levels of converting from $\mathrm{F} 2 \mathrm{~F}$ to $\mathrm{BL}$.

\section{Effective educational technology strategies must link the" Three Ts'} teaching, technology, and use of time--with overall whole-school reform strategies. Method with technology can use $70 \%$ online and $30 \% \mathrm{~F} 2 \mathrm{~F}$ interaction in classroom (free time and location), and use of internet student be center and highly motivated with high efficiency. The results applied on traditional teaching and online teaching with same exam. Started by $32 / 49$ participant in assignment 1 , to $50 / 50$ in final exam applied with BL. Conclusion show education was effective more than traditional, and student achievements was better.

The method move surrounding 6 institutions tested to adapt their policies. The general stages (setting, matching, restructuring, clarifying and routinizing). These institutions use different ways of $B L$ and online learning. In UCF $=53.401$ students enrolled with undergraduate as high research. The framework use strategy, structure, support to implement $\mathrm{BL}$. The analysis of data show teacher, student institute impact on BL and online courses. The results show most support to faculties rather than student. Where less work to increase student success in BL. Quasi experiment designed to test standardized exam of samples ( $\mathrm{N}$ 162), scores could be increased more than 3 grade points in collaborative study group based on SAT, GPA, Gender, pedagogy to balance student achievement. ANOVA regression model with $95 \%$ confidence capture $65 \%$ variance on exam, and high score above 3 is (Beta $=3.049$ ). SPSS used for hypothesis test. The method fix

Strang, (2013)

University accreditation and benchmarking: Pedagogy that increases student achievement students last year of BSBA program ANOVA $\mathrm{SE}=6.828$
The stakes use of instructor to help students to increase their scores in standard exams 列 sections. Use 4 factors to find model applied by faculties to improve SLO using TEL improve low student score in collaborative group. GPA $(b=.24, p<0.01)$, gender $(b=.18, p<0.05)$, SAT/ACT score $(b=.09, p$ $<0.01)$, and age $(b=.03, p<0.01)$, while ethnic culture was not significant. Population using z-tests $(p<0.05$, one-tailed, $N=6150)$ MFTB score $M=150.97, S D=11.52$. 
Table 4 (continued). The analyzed papers based on factors affect related to TEL

\begin{tabular}{|c|c|c|}
\hline Author & $\begin{array}{l}\text { Experiment } \\
\text { Studies }\end{array}$ & Moderator Variables \\
\hline $\begin{array}{l}\text { Cavanagh, et al, (2014). } \\
\text { The effect over time of a video- } \\
\text { based reflection system on } \\
\text { preservice teachers' oral } \\
\text { presentations }\end{array}$ & $\begin{array}{l}\text { High school } \\
N=47\end{array}$ & $\begin{array}{l}\text { Impression of communication acts } \\
\text { (confidence, clarity, engagement, and } \\
\text { appropriate). Interview ( } \mathrm{N}=47) \text {. Constructed } \\
\text { voice, body-language, words and alignment } \\
\text { between language, grammar are } \\
\text { communication with faculties by using video } \\
\text { based program. }\end{array}$ \\
\hline
\end{tabular}

\section{Method and Results}

The method use recorded presentation on video and uploaded to web site and evaluated by peers of teachers to develop their performance. It should be positive teacher- student relationship to improve student learning. Significant improvement for all criteria. Universities have major responsibilities of development employees. While limitation on university program for learning and reflections on work place. Method use sequence of videos used for students, parents, and last class of semester, then receive feedback on (language, present style, voice, etc.). The results of overall test give in 4 rounds of times as ( 1 vs. 2) $21.15, p<0.001$, (2 vs. 3) 6.70, (3 vs. 4) 0.06 , and round $4=41.50$. The best result found in time 2 , and less observation and reflection. This study good for beginner teachers in teaching and learning.

The main objective is identifying teacher expectation on professional program, and the difference between teacher expectations. The results collected in SWOT analysis. The quantitative analysis collected by SPSS. The results systemized in 7 dimensions as study focus. 13 members involved in execution and 12 members participate in survey. Notice the noteworthy increase 12 members participate in survey. Notice the noteworthy increase
the training course related to education. The second study results shows perception reflected on teacher training. The policymaker encourages universities. Useful for interesting in updating accreditation professional development program. undergraduate universities. The method used survey to the Accredited Programs for $\mathrm{N}=618$ develop evaluation reports, estimate the by Universities development area. IT cover three parts professional program, program level, and program population target.
Ozkan (2015)

Wikis and blogs in foreign language learning from the perspectives of learners

Adwan, (2016)

Dynamic online peer evaluations to improve group assignments in $\mathrm{M}=4.54$

Observations of students' experimental practice presentation. Wiki program, forum reaction, word attached to calculate students undergraduate perspectives of practice students' experimenta $\mathrm{N}=44+15 \quad$ presentation \& skills Collaborative problem based activity. Wiki findings give them confidence and communication level.

Evaluate individual and groups of assignments by online evaluation, activate, designed Google form, and peer evaluation form. Students will evaluate the presentation through peer evaluation and the faculty to improve their grades.

Al-Rahmi, \& Zeki, (2016) A Model of Using Social Media for Collaborative Learning to enhance learners' Performance on learning

Postgraduate, Use of social media internet items like Face undergraduates book, Blogs, YouTube in celebrative work to $\mathrm{N}=340$ enhance learner performance. There are Many factors significant relationship usefulness between weighted social media use and celebrative learning nursing e-learning environment $\quad \mathrm{SD}=0.48$

Even wiki have discomfort between students, but this can reduced by increasing some activities were members are shuffled periodically. The finding show significant effect on language learning by using wiki and blog. The finding of Usefulness of wik and blog as definitely agree are valid percent $52.3 \%$ and $38.6 \%$ respectively.

The method Use 3 types of color to inform student group of thei evaluation results to improve POs of group learning Color code peer evaluation results after assignment that solve the low marks of online assignments. Results of entire sample $\mathrm{M}=4.54, \mathrm{SD}=0.48$, and low performance $(\mathrm{N}=31) \mathrm{M}=3.64, \mathrm{SD}=0.63$

The method work on Technology Acceptance Model (TAM), Pointed interaction between learner $\&$ instructors, also find the most adaptation on social media used that improve learner better performance. The objectives show there significant relationship between (usefulness and multimedia) (usefulness and collaborative work). The finding results analyzed by SEM to check validity and influence of factors. The AVE for each contrast more than 0.5. the hypothesis positive and significant $(b=0.178, p<0.001)$, Cronbach's

Alpha $=0.908$

Test core self-evaluation (of learner) on academic performance. Positive learning

Debicki et al (2016) Debicki et al (2016)
Beyond the Big Five: The mediating undergraduates
prove performance Negative avoid
performance by 3 test of self-evaluation. Use role of goal orientation in the $\quad \mathrm{N}=307$ relationship between core self- $\quad M=3.833$ evaluations and academic $\quad \mathrm{SD}=0.563$ survey sample to measure individual's capabilities, worthiness on performance. Students themselves are good performance, success with Positive impact of core selfevaluation with AP.

performance

Web based era, faculties, and students Teacher develops more creative teaching

Lin, \& Wu, (2016)

Effects of Web-Based Creative

$E G=93$ methods to teach students. Use of web-based era changed the media of creative thinking teaching. Applying design of experiment to

\section{$\mathrm{CG}=93$}

Main works on High core self-evaluation is positively associated with both learning goal and prove performance goal. The results give $M=3.833, S D=0.563$. While academic performance gives $M=82.08$ $\mathrm{SD}=8.077$. Learning goal orientation doesn't have significant result on the model. Limited in job performance, job satisfaction.

The method use quasi experiment on $\mathrm{N}=186$ university students in Taiwan. The hypothesis of web based teaching positively affect creativity which affect learning outcomes. Results positively effect on creativity, learning outcomes and make up theoretical to web based creative thinking teaching. the quasi-experimental research.

The method use two sessions of 50 minutes in two weeks and teachers explain blog then given assignment that judgment by administrators. Investigation checks the using of video class in face

Use of video class in face to face enhance the
Liu M., (2016)

Blending a class video blog to optimize student learning outcomes in higher education. undergraduate $\mathrm{N}=21+21$ $\mathrm{M}=16.43$ $\mathrm{SD}=3.99$ university student learning performance and improve outcome .No big difference between 2 experiments group $(E G=21)$ and control group $(C G=21)$ of learning welling. to face could enhance the university student learning performance. Result shows positive join to Blog during learning process. The results Mean of average years of learning in both groups 9.2, 10.4. Mean of self-rated degree of English $E G=2.67, C G=3.5$. Final results EG's at the beginning of this study (Mean pre $=71.55 \mathrm{~N} 68.45$ ) after engaging (Mean post $=100.67 \mathrm{~N} 92.14, \mathrm{~F}=30.910, \mathrm{p} \mathrm{b} .05, \mathrm{~d}=1.72$ ). Outcomes show EG not significant increased.

Improve university by student satisfaction technology as high priority. Used survey quality model (SERVQUAL), with TEL
development, for student satisfaction an

Naidu, \& Derani, (2016)

A Comparative Study on Quality of $\mathrm{N}=50$ $\begin{array}{lll}\text { Education Received by Students of } & M=(4.56-2.18) & \text { development, for student satisfaction and } \\ \text { Private Universities versus Public } & S D=2.59-0.94 & \text { improve quality between public and private }\end{array}$ Private Universities versus Public $\quad \mathrm{SD}=2.59-0.94 \quad \begin{aligned} & \text { improve quality between public and priv } \\ & \text { colleges. Use of reliable, secure tangible, }\end{aligned}$ responsibility.
The main works are how do you rate quality of services, and how do you rate quality of teachers in university. The results give $(t=-8.08$, $\mathrm{P}=0.001)$, $(\mathrm{t}=-7.16, \mathrm{P}=0.001)$. Two types of results show private and public are significant satisfaction 
Table 4 (continued). The analyzed papers based on factors affect related to TEL

\begin{tabular}{|c|c|c|c|}
\hline Author & Experiment Studies & Moderator Variables & Method and Results \\
\hline $\begin{array}{l}\text { Posey \& Pintz, (2016) } \\
\text { Transitioning a bachelor of science } \\
\text { in nursing program to blended } \\
\text { learning: Successes, challenges \& } \\
\text { outcomes }\end{array}$ & $\begin{array}{l}\mathrm{N}=100,54 \text { flipped } \\
\text { classroom, } 44 \\
\text { collaborative } \\
\mathrm{M}=4.22 \\
\mathrm{SD}=0.60\end{array}$ & $\begin{array}{l}3 \text { projects, includes } 4 \text { stages: quality of peer } \\
\text { reviewer, pre and posttest of assessment, } \\
\text { assessment on student BL and interview } \\
\text { faculty perception by developing online } \\
\text { exam. }\end{array}$ & $\begin{array}{l}\text { The finding improves digital literature, improve independent } \\
\text { activity. Sufficient in success of implementing } B L \text {. It uses } 5 \text { likert } \\
\text { scales. Pre-test ( } M=274.7, S D=78.92) \text { to post-test }(M=263.9 \text {, } \\
S D=84.15) \text {. Finding gives online material are better than real } \\
\text { reading. }\end{array}$ \\
\hline $\begin{array}{l}\text { Trocky \& Buckley ,(2016) } \\
\text { Evaluating the impact of wikis on } \\
\text { student learning outcomes: an } \\
\text { integrative review. }\end{array}$ & $\begin{array}{l}\mathrm{N}=42 \\
\text { Many factors } \\
\text { weights }\end{array}$ & $\begin{array}{l}\text { Writing skills, collaboration, and knowledge } \\
\text { acquisition centralized repository on SLO } \\
\text { and co develop assignment. Effective tools } \\
\text { in improving writing performance through } \\
\text { create new ways to increase collaborative } \\
\text { learning. }\end{array}$ & $\begin{array}{l}\text { The method use quality rating by peer reviewer, pre-post } \\
\text { assessment of students, student perception on } B L \text { experience, } \\
\text { faculty interview. Two groups } E G=42, C G=42 \text {. Wiki encourage } \\
\text { students for more writing, reading, and grammar structure. } \\
\text { Group for accuracy }(F=49.0, P=.000) \text {, quality ( } F=66.7, P= \\
.003) \text {, and total score }(F=122.7, P=.000) \text {. Mixed } 4 \text { factors to } \\
\text { improve SLO \& develop assignments, instruction aid students in } \\
\text { learn knowledge. Limited with teaching learning strategies and } \\
\text { evaluating SLO }\end{array}$ \\
\hline $\begin{array}{l}\text { Wu, \& Tai, (2016) } \\
\text { Effects of Multimedia Information } \\
\text { Technology Integrated Multi- } \\
\text { Sensory Instruction on Students' } \\
\text { Learning Motivation and Outcome }\end{array}$ & $\begin{array}{l}\mathrm{N}=92 \\
\text { Many factors } \\
\text { weighted }\end{array}$ & $\begin{array}{l}\text { The factors integrated instruction, students' } \\
\text { learning motivation and interests. Teachers } \\
\text { used multimedia to enhance SLO } \\
\text { \&encourage SL confidence. Teachers apply } \\
\text { multimedia and information equipment to } \\
\text { teaching activities. And encourage students } \\
\text { to use multimedia for more confidence. }\end{array}$ & $\begin{array}{l}\text { Learning motivation has significant correlation on } L O \text {. } \\
\text { Multimedia information present remarkable on } L O \text {, and notable } \\
\text { with learning motivation. } L O \text { of curriculum }(B=2.342) \text {, learning } \\
\text { environment }(B=1.735) \text {, learning performance }(B=2.163) P<0.05 \text {. }\end{array}$ \\
\hline $\begin{array}{l}\text { Yousif \& Shaout, (2016) } \\
\text { Fuzzy logic computational model } \\
\text { for performance evaluation of } \\
\text { Sudanese University, academic } \\
\text { staff }\end{array}$ & $\begin{array}{l}\text { underg } \\
\mathrm{N}=46\end{array}$ & $\begin{array}{l}\text { Consistency check, aggregation, } \\
\text { approximate and final ranking to develop } \\
\text { learning outcomes. } 9 \text { criteria tested in Sudan } \\
\text { universities with } 3 \text { staff levels. Be consistence } \\
\text { between universities using new fuzzy } \\
\text { algorithm tool for experts. }\end{array}$ & $\begin{array}{l}\text { The study present fuzzy logic computational model and use AHP } \\
\text { and TOPSIS techniques. It design and compare through survey } \\
\text { distributed on expert to measure academic staff performance. } \\
\text { Returned questionnaire } 66 \% \text { of total } 70 \text { sent. Huge results } \\
\text { compared between factors and questions in relation with each } \\
\text { design path. }\end{array}$ \\
\hline $\begin{array}{l}\text { Lin, Chen, \&Liu,2017) } \\
\text { A Study of the Effects of Digital } \\
\text { Learning on Learning Motivation } \\
\text { and Learning Outcome }\end{array}$ & $\begin{array}{l}\mathrm{N}=116 \\
\text { Many factors of } \\
\text { weights }\end{array}$ & $\begin{array}{l}\text { Design Teaching activity on digital learning } \\
\text { and matching with teach technology tools, } \\
\text { test such different digital learning, } \\
\text { experience added to teachers. Digital } \\
\text { material, digital tools, digital delivery to } \\
\text { reduce time consume with digital learning. }\end{array}$ & $\begin{array}{l}\text { Digital learning positively effect on learning motivation and } \\
\text { reveal positively on learning outcomes (LO). Intrinsic and } \\
\text { extrinsic of learning }(0.202,0.173) \text { respectively. While leaning } \\
\text { motivation positively effect on LO. Accepted teachers new } \\
\text { teaching strategies, create digital learning lies on teachers, } \\
\text { design a flexibility technology tools and more interactive with } \\
\text { teachers. }\end{array}$ \\
\hline $\begin{array}{l}\text { Chmiel, Shaha, \& Schneider, (2017) } \\
\text { Introduction of blended learning in } \\
\text { a master program: Developing an } \\
\text { integrative mixed method } \\
\text { evaluation framework }\end{array}$ & $\begin{array}{l}\mathrm{N}=25 \\
\text { Many pointed } \\
\text { weighted }\end{array}$ & $\begin{array}{l}\text { Establish principles; evaluate } B L \text {, by } 2 \\
\text { recurrence programs. Documented the } \\
\text { power \& weakness of BL, Work to increase } \\
\text { capacities to succeed in BL \& setting. } \\
\text { Establish standards \& concept of evaluation. } \\
\text { Then tools related to student, faculty, and } \\
\text { admin. }\end{array}$ & $\begin{array}{l}\text { The method use multimodal evaluation to wrap up of different } \\
\text { measures. Two factors checked in the study usability of tools } 3.6 \\
(\mathrm{~s}=0.5) \text {, quality of support } 3.7 \text {. In addition improvement at } \\
\text { program, faculty and educational level through evaluation of } \\
\text { program proceed. Propose to develop mixed-method of } \\
\text { monitoring BL, integrative work. }\end{array}$ \\
\hline $\begin{array}{l}\text { Wilby, et al, (2017) } \\
\text { Development of a college-level } \\
\text { assessment framework in line with } \\
\text { international accreditation } \\
\text { standards: A Middle Eastern } \\
\text { perspective. }\end{array}$ & Un-weighted values & $\begin{array}{l}\text { Step of accreditation standard. } \\
\text { Programmatic assessment, academics, and } \\
\text { satisfaction Create committee mix of factors } \\
\text { to revise exams. The results measures } 3 \\
\text { types of programmatic assessment, faculty } \\
\text { and learner satisfaction on PLO and } \\
\text { cumulative assessment. }\end{array}$ & $\begin{array}{l}\text { Method use of committee of dean, faculty, student and } \\
\text { administrator members grouped for assessment and quality they } \\
\text { develop the framework and extract results. Results used } \\
\text { comprehensive framework of } 3 \text { components and related } \\
\text { assessment of mission, vision and standards. It conclude can } \\
\text { coordinate assessment and support program. }\end{array}$ \\
\hline
\end{tabular}

\section{CONCLUSIONS}

This study has reviewed 24 previous studies from (2011-2017) that have used TEL under three academic criteria of accreditation process which are the SLO, TEL, and FE. All of them work together to develop the use of online internet connection. From the viewpoint of viewing assessment and evaluation, it is supposed to clarify the relations of certain practices between faculty experience, evaluation of assessment and students achievements. On the other hand, of the standpoint, it is seen as a joint assessment effort performed by faculties of universities and institutes. Nevertheless, in educational claims the assessors' efforts install the idea of merge criteria's, it seems that the first conception strongly prevails.

The paper discuss the impact that TEL has on the teacher-student experience and does learning really takes place in educational process to improve SLOs. The analyzed studies demonstrated that three common techniques used mostly with these key elements (tool, tool with traditional guidance and traditional). These tool- techniques include online conversation specially (wiki programs) to keep link conversation with students, the video Blog programs to guide students for understanding material and the Google form drives that is used for all evaluation types in teaching, and assessment method. The technology development tools are aided to improve student skills and to facilitate interaction with their peers.TEL goals; creates meaningful feedback; identifies needs; modeling strategies; providing guided and independent practice; providing students with control of their learning (Schwartzbeck \& Wolf, 2012). 
EURASIA J Math Sci and Tech Ed

Table 5. The effect of analyzed papers based on factors affect related to TEL

\begin{tabular}{|c|c|c|c|c|c|c|c|c|c|c|c|c|c|c|}
\hline \multirow[t]{2}{*}{ Author/year } & \multicolumn{3}{|c|}{$\begin{array}{l}\text { Student Learning } \\
\text { Outcomes }\end{array}$} & \multicolumn{3}{|c|}{$\begin{array}{c}\text { Assessment } \\
\text { Method } \\
\text { Techniques }\end{array}$} & \multicolumn{3}{|c|}{$\begin{array}{l}\text { Teaching } \\
\text { Experience }\end{array}$} & \multicolumn{3}{|c|}{$\begin{array}{c}\text { University } \\
\text { Performance }\end{array}$} & \multirow{2}{*}{$\begin{array}{c}\text { Participant } \\
\text { Total }\end{array}$} & \multirow[t]{2}{*}{ Impact On } \\
\hline & $\mathbf{T}$ & TG & ThW & $\mathbf{T}$ & TG & ThW & $\mathbf{T}$ & TG & ThW & $\mathbf{T}$ & TG & ThW & & \\
\hline Bell \& Youngs. 2011 & & & Y & $\mathrm{Y}$ & & & & Y & & & & Y & 17 & $\begin{array}{l}\text { Teacher education } \\
\text { program }\end{array}$ \\
\hline O'Bannon, Britt 2011 & & & & & & $\mathrm{Y}$ & $\mathrm{Y}$ & & & & & $\mathrm{Y}$ & 400 & Student achievement \\
\hline Abdullah, et al, 2012 & & & $\mathrm{Y}$ & & & $\mathrm{Y}$ & $Y$ & & & & & $\mathrm{Y}$ & None & Improve quality \\
\hline Joseph 2012 & & $\mathrm{Y}$ & & & & Y & & $\mathrm{Y}$ & & & & Y & None & $\begin{array}{l}\text { Teacher-student } \\
\text { experience }\end{array}$ \\
\hline Schwartzbeck, \& Wolf 2012 & & $\mathrm{Y}$ & & & & $\mathrm{Y}$ & $\mathrm{Y}$ & & & $Y$ & & & $\mathrm{~N}=100$ & Teaching technology \\
\hline Beleche, et al, (2012) & $\mathrm{Y}$ & & & & & $\mathrm{Y}$ & & & $\mathrm{Y}$ & $Y$ & & & $700+300$ & Student learning \\
\hline Bell \& Youngs. 2011 & & & Y & $\mathrm{Y}$ & & & & $\mathrm{Y}$ & & & & Y & 17 & $\begin{array}{l}\text { Teacher education } \\
\text { program }\end{array}$ \\
\hline O'Bannon, Britt 2011 & & & & & & Y & $\mathrm{Y}$ & & & & & Y & 400 & $\begin{array}{l}\text { Student } \\
\text { achievement }\end{array}$ \\
\hline Abdullah, et al, 2012 & & & Y & & & Y & $\mathrm{Y}$ & & & & & Y & None & $\begin{array}{l}\text { Improve } \\
\text { quality }\end{array}$ \\
\hline Joseph 2012 & & Y & & & & Y & & $\mathrm{Y}$ & & & & Y & None & $\begin{array}{l}\text { Teacher-student } \\
\text { experience }\end{array}$ \\
\hline Schwartzbeck, \& Wolf 2012 & & $Y$ & & & & $\mathrm{Y}$ & $\mathrm{Y}$ & & & $Y$ & & & $\mathrm{~N}=100$ & Teaching technology \\
\hline Beleche, et al, (2012) & $\mathrm{Y}$ & & & & & $\mathrm{Y}$ & & & $\mathrm{Y}$ & $\mathrm{Y}$ & & & $700+300$ & Student learning \\
\hline Graham, et al, (2013) & $\mathrm{Y}$ & & & & & $\mathrm{Y}$ & & & $\mathrm{Y}$ & & & Y & None & $\begin{array}{l}\text { Institution policy } \\
\text { adapted }\end{array}$ \\
\hline Strang (2013) & & & $\mathrm{Y}$ & $\mathrm{Y}$ & & & $\mathrm{Y}$ & & & & & Y & 162 & $\begin{array}{l}\text { Increase student } \\
\text { achievement }\end{array}$ \\
\hline Cavanagh, et al, (2014) & & & & & & Y & & & Y & $\mathrm{Y}$ & & & 47 & $\begin{array}{l}\text { Pre-service teacher } \\
\text { presentation }\end{array}$ \\
\hline Crețu \& Rogoz, (2014) & & & & & & $\mathrm{Y}$ & & $\mathrm{Y}$ & & & & $\mathrm{Y}$ & 618 & Teacher expectation \\
\hline Ozkan (2015) & & & & & $\mathrm{Y}$ & & & & $\mathrm{Y}$ & & & & 59 & Improve learner \\
\hline Adwan, (2016) & & $\mathrm{Y}$ & & & & & $\mathrm{Y}$ & & $\mathrm{Y}$ & & & & 279 & Student learning \\
\hline Al-Rahmi, \& Zeki, (2016) & $Y$ & & & & $\mathrm{Y}$ & & & & $Y$ & & $\mathrm{Y}$ & & 340 & Learner performance \\
\hline Debicki et al (2016) & & & & & & Y & & $\mathrm{Y}$ & & & $\mathrm{Y}$ & & 307 & $\begin{array}{l}\text { self-evaluations and } \\
\text { academic performance }\end{array}$ \\
\hline Lin, \& Wu, (2016) & $\mathrm{Y}$ & & & & $\mathrm{Y}$ & & & & $\mathrm{Y}$ & & & $Y$ & 186 & Teaching on SLO \\
\hline Liu M., (2016) & $\mathrm{Y}$ & & & $\mathrm{Y}$ & & & & & $Y$ & $Y$ & & & 42 & Optimize SLO \\
\hline Naidu, Derani, (2016) & & $Y$ & & $\mathrm{Y}$ & & & $\mathrm{Y}$ & & & & $\mathrm{Y}$ & & 50 & Teacher quality \\
\hline Posey \& Pintz, (2016) & & & $\mathrm{Y}$ & & & & & & $\mathrm{Y}$ & & & $\mathrm{Y}$ & 37 & Nurse education \\
\hline Trocky,Buckley (2016) & & $\mathrm{Y}$ & & & $\mathrm{Y}$ & & $\mathrm{Y}$ & & & $\mathrm{Y}$ & & & 42 & SLO \\
\hline Wu, \& Tai, (2016) & & $\mathrm{Y}$ & & & $\mathrm{Y}$ & & $\mathrm{Y}$ & & & & & $\mathrm{Y}$ & 92 & SLO \\
\hline Yousif, Shaout, (2016) & & $Y$ & & $Y$ & & & & $\mathrm{Y}$ & & & $\mathrm{Y}$ & & 46 & Staff performance \\
\hline Lin, Chen, \&Liu, (2017) & & $\mathrm{Y}$ & & & $\mathrm{Y}$ & & & & $\mathrm{Y}$ & & & $\mathrm{Y}$ & 116 & SLO \\
\hline Chmiel, et al, (2017) & & & & & & $Y$ & & & $\mathrm{Y}$ & & & & 25 & Evaluation accreditation \\
\hline Wilby, et al, (2017) & & $Y$ & & & & $\mathrm{Y}$ & $\mathrm{Y}$ & & & & $\mathrm{Y}$ & & None & Assessment quality \\
\hline
\end{tabular}

As for the accreditation process, the link with the self-evaluators and UP are carried out by means of the technician, faculty, mangers who eventually interested and experienced in technology. These technologies give level by level explanations or add values to student achievements and graduates outcomes. The referents from different academic programs implementation have confirmed that academic program assessments have consolidated essential practices. These practices have relation with other factors such as priorities in the technology of the particular projects. Therefore, the need for more studies that focuses on using TEL in assessment and teaching experience are required to develop the academic performance.

Based on the findings of analyzed papers technology was used in collaboration with traditional teaching it impacted positively on the education experience for all of the learner, faculty and university. The use of technology guarantees that students could work independently, increased communication and collaboration and have greater access to information with high confidence of assessment. Also, it shows the real need to develop the assessment method and it affection on SLO and academic performance of graduated students. This development confirms increase the trust and use of TEL in educational process. 


\section{REFERENCES}

Abdullah, S., Wahab, D. A., \& Hussein, S. M. (2012). Development of a Quality Assurance Plan in Line with UKM's Status as a Self-accreditation Institution and Research University. Procedia-Social and Behavioral Sciences, 59, 95-104. https:// doi.org/10.1016/j.sbspro.2012.09.251

Adwan, J. (2016). Dynamic online peer evaluations to improve group assignments in nursing e-learning environment. Nurse education today, 41, 67-72. http:/ / dx.doi.org/10.1016/j.nedt.2016.03.028

Aldiab, A., Chowdhury, H., Kootsookos, A., \& Alam, F. (2017). Prospect of eLearning in Higher Education Sectors of Saudi Arabia: A Review. Energy Procedia, 110, 574-580. https:/ / doi.org/10.1016/j.egypro.2017.03.187

Al-Rahmi, W. M., \& Zeki, A. M. (2016). A Model of Using Social Media for Collaborative Learning to enhance learners' Performance on learning. Journal of King Saud University-Computer and Information Sciences, 29(4), 526-535. http:/ / dx.doi.org/10.1016/j.jksuci.2016.09.002

Alshumaimeri, Y. (2011). The effects of wikis on foreign language students writing performance. Procedia-Social and Behavioral Sciences, 28, 755-763. https:/ / doi.org/10.1016/j.sbspro.2011.11.139

Apandi, S. H., \& Arshah, R. A. (2015). The Need of Dashboard in Social Research Network Sites for Researchers. International Journal of Software Engineering and Computer Systems, 2(1), 120-132.

Barak, M., \& Levenberg, A. (2016). Flexible thinking in learning: An individual differences measure for learning in technology-enhanced environments. Computers $\mathcal{E}$ Education, 99, 39-52. https://doi.org/10.1016/j.compedu.2016.04.003

Becher, M. (2013). Instruction coordinators and higher education accreditation: A study of awareness and assessment documentation use. The Journal of Academic Librarianship, 39(6), 573-581. http:/ /dx.doi.org/10.1016/j.acalib.2013.04.003

Beleche, T., Fairris, D., \& Marks, M. (2012). Do course evaluations truly reflect student learning? Evidence from an objectively graded post-test. Economics of Education Review, 31, 709- 719. http:/ / dx.doi.org/10.1016/j.econedurev.2012.05.001

Bell, C. A., \& Youngs, P. (2011). Substance and show: Understanding responses to teacher education programme accreditation processes. Teaching and teacher education, 27(2), 298-307. https:/ / doi.org/10.1016/j.tate.2010.08.012

Benson, P. (2013). Teaching and researching: Autonomy in language learning. London: Routledge.

Bourke, T., Ryan, M., \& Lloyd, M. (2016). The discursive positioning of graduating teachers in accreditation of teacher education programs. Teaching and Teacher Education, 53, 1-9.

Cavanagh, M., Bower, M., Moloney, R., \& Sweller, N. (2014). The effect over time of a video-based reflection system on preservice teachers' oral presentations. Australian Journal of Teacher Education (Online), 39(6), 1. http:/ / dx.doi.org/10.14221/ajte.2014v39n6.3

Chmiel, A. S., Shaha, M., \& Schneider, D. K. (2017). Introduction of blended learning in a master program: Developing an integrative mixed method evaluation framework. Nurse education today, 48, 172-179. http://dx.doi.org/10.1016/j.nedt.2016.10.008

Crețu, C. M., \& Rogoz, N. (2014). Teachers' Expectations Regarding the Accredited Programs for Professional Development Provided by Universities. Procedia-Social and Behavioral Sciences, 142, 660-667. https:// doi.org/10.1016/j.sbspro.2014.07.682

Davis, S. W., Weed, D., \& Forehand, J. W. (2015). Improving the nursing accreditation process. Teaching and Learning in Nursing, 10(1), 35-38. https:/ / doi.org/10.1016/j.teln.2014.09.003

De Wever, B., Hämäläinen, R., Voet, M., \& Gielen, M. (2015). A wiki task for first-year university students: The effect of scripting students' collaboration. The Internet and Higher Education, 25, 37-44. https:// doi.org/10.1016/j.iheduc.2014.12.002

Debicki, B. J., Kellermanns, F. W., Barnett, T., Pearson, A. W., \& Pearson, R. A. (2016). Beyond the Big Five: The mediating role of goal orientation in the relationship between core self-evaluations and academic performance. The International Journal of Management Education, 14(3), 273-285. http:/ / dx.doi.org/10.1016/j.ijme.2016.05.002

Graffigna, A. M. (2015). Effect of Institutional Evaluation Policies on Private Universities in the Cuyo Region. Procedia-Social and Behavioral Sciences, 197, 334-338. https:// doi.org/10.1016/j.sbspro.2015.07.146

Graffigna, A. M., Ghilardi, L., Fraca, C., de los Ángeles Morell, M., Simonassi, M. L., Bartol, R., \& Mengual, M. (2014). Universitary Evaluation. From the Program's Accreditation to the Institutional Evaluation. ProcediaSocial and Behavioral Sciences, 116, 2635-2639. https:/ / doi.org/10.1016/j.sbspro.2014.01.626 
Graham, C. R., Woodfield, W., \& Harrison, J. B. (2013). A framework for institutional adoption and implementation of blended learning in higher education. The internet and higher education, 18, 4-14. http:/ / dx.doi.org/10.1016/j.iheduc.2012.09.003

Grover, K. S., Miller, M. T., Swearingen, B., \& Wood, N. (2014). An examination of the self-directed learning practices of ESL adult language learners. Journal of Adult Education, 43(2), 12.

Hashim, A. A., \& Majid, M. A. (2015). Effects of Video Display Terminal Resolutions to the Legibility of Text on a Web Page. International Journal of Software Engineering and Computer Systems, 1(1), 131-157. http:/ / dx.doi.org/10.15282/ijsecs.1.2015.11.0011

Heflin, H., Shewmaker, J., \& Nguyen, J. (2017). Impact of mobile technology on student attitudes, engagement, and learning. Computers \& Education, 107, 91-99. https:/ / doi.org/10.1016/j.compedu.2017.01.006

Joseph, J. (2012). The barriers of using education technology for optimizing the educational experience of learners. Procedia-Social and Behavioral Sciences, 64, 427-436. https:/ / doi.org/10.1016/j.sbspro.2012.11.051

Kleebbua, C., \& Siriparp, T. (2016). Effects of Education and Attitude on Essential Learning Outcomes. ProcediaSocial and Behavioral Sciences, 217, 941-949. https://doi.org/10.1016/j.sbspro.2016.02.061

Lancaster, J. W., Wong, A., \& Roberts, S. J. (2012). 'Tech'versus 'Talk': A comparison study of two different lecture styles within a Master of Science nurse practitioner course. Nurse education today, 32(5), e14-e18. https:/ / doi.org/10.1016/j.nedt.2011.09.018

Laurillard, D. (2008). Digital technologies and their role in achieving our ambitions for education. Institute of Education, University of London.

Lee, C., Yeung, A. S., \& Ip, T. (2017). University English language learners' readiness to use computer technology for self-directed learning. System, 67, 99-110. http://dx.doi.org/10.1016/j.system.2017.05.001

Lin, C. S., \& Wu, R. Y. W. (2016). Effects of Web-Based Creative Thinking Teaching on Students' Creativity and Learning Outcome. Eurasia Journal of Mathematics, Science $\mathcal{E}$ Technology Education, 12(6), 1675-1684. https:// doi.org/10.12973/eurasia.2016.1558a

Lin, M. H., Chen, H. C., \& Liu, K. S. (2017). A Study of the Effects of Digital Learning on Learning Motivation and Learning Outcome. Eurasia Journal of Mathematics, Science and Technology Education, 13(7), 3553-3564. https:/ / doi.org/10.12973/eurasia.2017.00744a

Liu, M. H. (2016). Blending a class video blog to optimize student learning outcomes in higher education. The Internet and Higher Education, 30, 44-53. http:/ / dx.doi.org/10.1016/j.iheduc.2016.03.001

Malik, S., \& Coldwell-Neilson, J. (2016). Comparison of Traditional and ADRI Based Teaching Approaches in an Introductory Programming Course. Journal of Information Technology Education: Research, 16(1), 267-283.

Michelson, D. G., Tong, W., \& Reeves, L. (2015). Communications education and training: industry certification and university accreditation [Guest Editorial]. IEEE Communications Magazine, 53(5), 194-195.

Naidu, P., \& Derani, N. E. S. (2016). A Comparative Study on Quality of Education Received by Students of Private Universities versus Public Universities. Procedia Economics and Finance, 35, 659-666. https:/ / doi.org/10.1016/S2212-5671(16)00081-2

O'Bannon, B., \& Britt, V. G. (2011). Creating/developing/using a wiki study guide: Effects on student achievement. Journal of Research on Technology in Education, 44(4), 293-312.

Ozkan, M. (2015). Wikis and blogs in foreign language learning from the perspectives of learners. Procedia-Social and Behavioral Sciences, 192, 672-678. https:/ / doi.org/10.1016/j.sbspro.2015.06.102

Pinedo, M., Chiyón, I., \& Pérez, F. (2012). The influence of transparency on self-evaluation as part of the university accreditation process in Peru. Procedia-Social and Behavioral Sciences, 46, 1069-1076. https://doi.org/10.1016/j.sbspro.2012.05.250

Posey, L., \& Pintz, C. (2017). Transitioning a bachelor of science in nursing program to blended learning: Successes, challenges \& outcomes. Nurse Education in Practice, 26, 126-133. http:/ / dx.doi.org/10.1016/j.nepr.2016.10.006

Ralph, N., Birks, M., \& Chapman, Y. (2015). The accreditation of nursing education in Australia. Collegian, 22(1), 37. http://dx.doi.org/10.1016/j.colegn.2013.10.002

Salajan, F. D., \& Mount, G. J. (2012). Leveraging the power of Web 2.0 tools: a Wiki platform as a multimedia teaching and learning environment in dental education. Journal of dental education, 76(4), 427-436.

Schneider, C. G. (2016). Policy Priorities for Accreditation Put Quality College Learning at Risk. Liberal Education, 101(1).

Schwartzbeck, T. D., \& Wolf, M. A. (2012). The Digital Learning Imperative: How Technology and Teaching Meet Today's Education Challenges. Digital Learning Series. Alliance for Excellent Education. 
Strang, K. D. (2013). University accreditation and benchmarking: Pedagogy that increases student achievement. International Journal of Educational Research, 62, 210-219. http:/ / dx.doi.org/10.1016/j.ijer.2013.09.007

Trocky, N. M., \& Buckley, K. M. (2016). Evaluating the impact of wikis on student learning outcomes: an integrative review. Journal of professional nursing, 32(5), 364-376. http:/ / dx.doi.org/10.1016/j.profnurs.2016.01.007

Wang, F., \& Hannafin, M. J. (2005). Design-based research and technology-enhanced learning environments. Educational technology research and development, 53(4), 5-23. http:/ / www.jstor.org/stable/30221206

Wilby, K. J., Zolezzi, M., Rachid, O., \& El-Kadi, A. (2017). Development of a college-level assessment framework in line with international accreditation standards: A Middle Eastern perspective. Currents in Pharmacy Teaching and Learning, 9(1), 115-120. http:/ / dx.doi.org/10.1016/j.cptl.2016.08.028

Wu, T. J., \& Tai, Y. N. (2016). Effects of Multimedia Information Technology Integrated Multi-Sensory Instruction on Students' Learning Motivation and Outcome. EURASIA Journal of Mathematics, Science E Technology Education, 12(4), 1065-1074. https:// doi.org/10.12973/eurasia.2016.1552a

Yigit, T., Koyun, A., Yuksel, A. S., \& Cankaya, I. A. (2014). Evaluation of blended learning approach in computer engineering education. Procedia-Social and Behavioral Sciences, 141, 807-812. https://doi.org/10.1016/j.sbspro.2014.05.140

Yousif, M. K., \& Shaout, A. (2016). Fuzzy logic computational model for performance evaluation of Sudanese Universities and academic staff. Journal of King Saud University-Computer and Information Sciences. http:/ / dx.doi.org/10.1016/j.jksuci.2016.08.002

\section{http://www.ejmste.com}

